\title{
ASTHENIA HYPOPHYSOPRIVA
}

\section{Neuromuscular Symptoms Due To Alterations In The Pituitary}

\author{
BY BERNARDO A. HOUSSAY, M.D. $\dagger$
}

\begin{abstract}
A STHENIA is one of the most interesting symptoms of pituitary insufficiency; it always occurs in the toad and, though in a lesser degree, in the rat; it manifests itself in man in the course of pituitary cachexia and is also seen, with varying frequency, in other species. It is well marked in the advanced stages of severe forms of pituitary insufficiency, coexisting with general and metabolic symptoms and with modifications of behavior in animals and of mental reactions in man. It seems to be the result of a general nutritive change, which principally affects the central nervous system but also affects the chemical reactions of the muscle. The toad is the animal par excellence for the observation and analysis of this phenomenon.
\end{abstract}

\section{Experimental pituitary insufficiency}

Dogs.--After removal of the pituitary gland in dogs some symptoms appear immediately, others do not occur until later. The former, described by Vassale and Sacchi, ${ }^{116}$ are depression, apathy, tameness, docility and passivity, sleepiness; fibrillary muscular contractions, rigidity of the hind legs, arching of the back, halting gait, sometimes tonoclonic convulsions during which death may occur; anorexia, with occasional vomiting; frequently polyuria and polydipsia ; rapid and progressive wasting. The following symptoms have been observed by many investigators: (1) the depression, apathy or indifference is very frequent in the first days after operation ${ }^{11,22,24}$, $31,32,40,42,97,117$, etc. although in our experience it varies considerably in degree; (2) a lowering

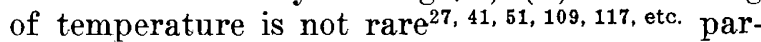
ticularly in the fatal cases; (3) lethargy or somnolence are very common and at times extreme but are transient; (4) loss of weight or cachexia ${ }^{22,24,31,41}$ have not been very marked in our observations except in cases with polyuria and anorexia; (5) motor symptoms, i.e., contractures, rigidity of the neck, fibrillary twitchings, curving of the back, hanging of the head, usually do not occur if the operation has been performed with care. The defecatory attitude, associated with apathy, low temperature and low blood pressure, followed by coma and death $\ddagger$ which Cushing and his collaborators consider typical of the cachexia of pituitary insufficiency, is also produced by lesions in the neighborhood

†Houssay, Bernardo A.-Professor of Physiology, Faculty of Medical Sciences, University of Buenos Aires, 1919-. For record and address of author see "This Week's Issue," page 946, issue of May 7

$\$$ Mahoney ${ }^{78}$ found a marked hypoglycemia, which he considered the cause of death; sugar produced an improvement in the condition of the animals. of the pituitary ${ }^{87}$ or by tuberal puncture which does not touch the pituitary. ${ }^{7}$ We can definitely state from wide experience that these symptoms are observed more often and with greater intensity (particularly the convulsions and motor symptoms) when tuberal lesions occur or when blood clots are left in the sella turcica, while there is only slight depression (inconstant in puppies) and sleepiness, and slight loss of appetite if the pituitary is removed skillfully with minimum trauma.

The late symptoms, that is to say those occurring when the dogs have recovered from the first operative effects, are more interesting. Caselli $^{22}$ observed psychic depression, in that the dogs were apathetic, quiet, patient, their intelligence dull and their gait slow. Crowe, Cushing and Homans ${ }^{27}$ observed adiposity and genital atrophy and often psychical depression, with inactivity and somnolence, although certain of their dogs played ceaselessly and many were irritable. Aschner ${ }^{2}$ mentioned slight depression in the adult with a decrease, though never a complete suppression, of the sexual impulse; puppies were quiet, moved little and had sluggish tempers. Ascoli and Legnani ${ }^{3}$ mentioned the psychical and physical weakness; Koster and Geesink ${ }^{66}$ and Reichert ${ }^{93}$ described loss of vivacity. Since 1912 we have found that some animals are apathetic and sleep much of the time, being patient and little responsive to stimuli (either pleasant or unpleasant); but others retain their vivacity and like to play. There are many intermediate degrees between these two extremes.

In general the hypophysectomized animals. are docile, tame and quiet, and easily trained to remain immobile. The intense degree of depression may be observed also in certain dogs with tuberal lesions, while others of these may become irritable, savage and wild, or on the contrary, very timid. ${ }^{109}$

Although the tameness and docility are frequent and significant in hypophysectomized animals, one cannot speak of real asthenia or cachexia as occurring in all of the animals. Nevertheless, from time to time, even when in apparently good condition, they may spontaneously, or as a result of some infection, trauma or fasting, become anorexic, apathetic and progressively cachectic, dying in a marasmic condition with or without hypoglycemia. In. other similar cases death may suddenly occur in hypoglycemic or repeated epileptoid convul-. sions. 
The conditioned reflexes were studied by Kriaschew ${ }^{68}$ in two dogs. He found that they behaved in an infantile fashion and showed a general diminution of excitability and $a$ diminished electrical excitability of the skin. Conditioned reflexes were produced by different stimuli (cutaneous, auditory and visual), but there were certain peculiarities; (1) irradiation was diminished, e.g., only the stimulated paw responded instead of the reaction becoming generalized; (2) the response ended directly the stimulus was removed, which is contrary to what occurs in normal animals; (3) there was a rapid disappearance of the conditioned reflex. Cortical co-ordination was weak and the sexual reflexes, cries, etc., were absent. The higher nervous activities seemed to become fragmentary with almost complete independence of the cortical centres and their reflex function. A histological study was made five and a half years after the operation (removal of the pituitary and lesion of the tuberal region) revealing pathologic degenerative changes in the cortex and hypothalamus.

Horsley, ${ }^{49}$ in two dogs five to six months after hypophysectomy, observed that there was hyperexcitability of the motor cortex to faradic stimulation, which produced a severe tetanus followed by protracted and severe epilepsy (the most prolonged seen in $\operatorname{dogs}$ ), with rapid clonic spasms (24 per second). This epilepsy ended "by the occurrence of a tremendous spasm, instead of a gradual dying out of the clonic spasm".

Pituitary insufficiency in animals produces an increased sensitivity to anesthetics, to blood sugar lowering agents (insulin, phlorhizin, etc.) and to blood pressure lowering agents (histamin, bleeding, etc.). Hypophysectomized dogs are extremely sensitive to the toxic action of chloralose. Our mortality for the first week after operation dropped from 75 per cent to 15 per cent when, in 1932, we substituted ether for chloralose anesthesia. (On the other hand animals treated with thyroid or thyrotropic hormone require a larger dose of chloralose than normally.) Two out of ten hypophysectomized dogs showed grave symptoms with only $30 \mathrm{Mgm}$. of morphine hydrochloride per $\mathrm{Kgm}$. body weight subcutaneously, and one died (di Benedetto, unpublished).

Rats.-Hypophysectomized rats are weak, unsteady, and less active; they lose weight and become cachectic. They grow prematurely senile according to Smith. ${ }^{10 \tau, 108}$ Koyama $^{67}$ found asthenia, lessened muscular turgidity and later cachexia. The loss of activity has been recorded graphically by Richter and Wislocki.96* Implantation of the pituitary gland corrects

"Tuberal lesions (with section of the pituitary stalk) produce a decrease in spontaneous movements, alternating with cycles of activity lasting nine to eighteen days.95 all the symptoms. ${ }^{107,108}$ Alkaline extract of bovine anterior pituitary lobe immediately tends to restore the strength, muscular tone and turgidity of the tissues in all cases, so that within ten days of its administration the characteristic myasthenia of hypophysectomized animals disappears. ${ }^{37,38}$ The gonadotropic extract, however, does not alter these symptoms. ${ }^{38}$ Asthenia is not caused by ablation of the posterior lobe $\mathrm{l}^{108}$ or by partial hypophysectomy.

other species.-Hypophysectomized cats, some time after the operation, feed well but are apathetic and less playful than are normal cats: ${ }^{77}$ Rabbits may appear cachectic within a few days ${ }^{98,99}$ or improve and appear normal for some time, but later again become indolent ${ }^{119}$ or even cachectic.

The hypophysectomized ferret cannot be distinguished from the normal except for being somewhat lethargic. ${ }^{48}$ Hypophysectomized chickens usually die in forty-eight hours, sometimes in convulsions; those which survive are not quarrelsome though they will still fight. ${ }^{47}$

Toads. A neuromuscular syndrome appears in hypophysectomized amphibians some weeks after operation and gradually becomes worse, terminating in death.* It is necessary to differentiate this syndrome from certain initial or early symptoms which may occur.

The initial symptoms are rare and are due to lesions of the nervous system at operation; the animals become enormously distended owing to urine in the paralyzed bladder; they become paretic, with the legs abducted; sometimes they have opisthotonos with infrequent movements, at other times there are tonic and tonoclonic convulsions. Most animals with these symptoms die in a few days, but a small number recover.

On the other hand hypophysectomized toads (or toads from which the principal lobe has been removed) always become asthenic or adynamic at a later stage. The asthenia makes its appearance in from ten to fifteen days after total hypophysectomy. When only the principal lobe is removed it occurs a little later, although more than half of the animals have asthenia by the end of the third postoperative week. Death occurs three to thirty days after the appearance of the asthenia, most of the toads $\mathrm{dy}$ ing between four and seven weeks after operation. $f$ This is rarely observed in toads with lesions of the infundibulotuberal region (10-15 per cent in two of our groups). The asthenia of *This has been observed in Leptodactylus ocellatus, ${ }^{5051}$ in $B$ fo arenarum Hensell, 52536 and in Bufo d'Orbigny, Ceratophrys ormata and Hyla sp.52 53

$\dagger$ In our experience exceptional cases. developed no asthenia and survived for three or even five and a half months. Anatomical examination of these disclosed that, though the principal lobe had been removed, the neuro-intermediate lobe was conserved and showed certain peculiarities. In a few places in the pars intermedia there were groups of two to six acidophilic and basophilic cells. It is possible that in these animals the neurointermediate lobe, probably the pars intermedia, took over the
metabolic functions of the absent glandular lobe. 
the latter preparations was in consequence of secondary destructive lesions of the principal lobe of the pituitary. ${ }^{54,70}$

After asthenia has developed certain minor remissions and relapses are to be noted, but the general course is downwards, terminating in death. The first symptom to appear is an al- since reactions with rapid, forceful movements to other stimuli are still possible.

Later in the course of the asthenia the resting posture and the gait alter. When at rest the head is held lower, the legs more abducted and the muscles more flaccid than is the case in normal animals. All movements are slow and

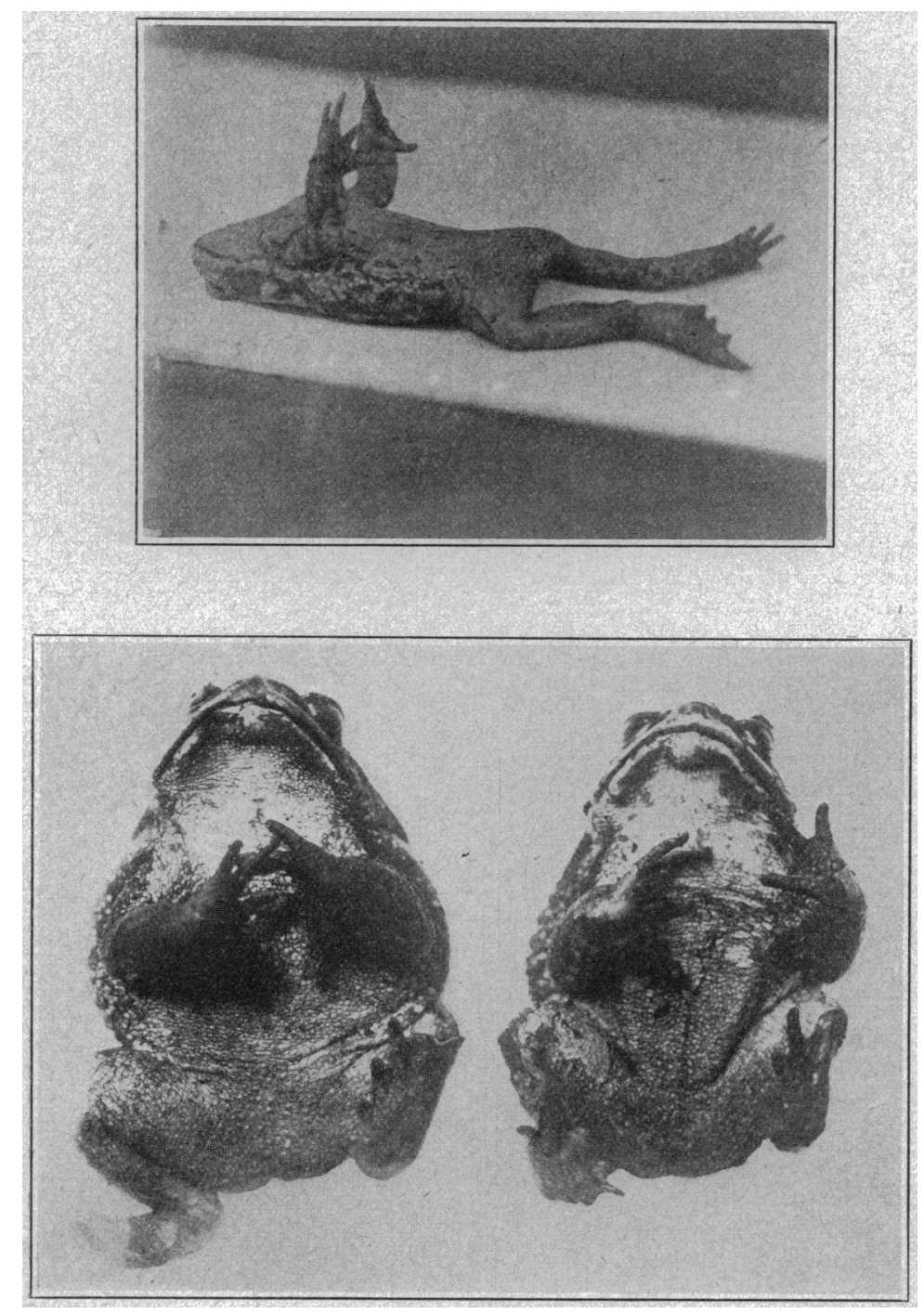

FIG. 1.

Asthenia hy pophysopriva in the toad showing typical postures and the loss of the righting reflex.

teration in the postural reflex whereby the natural position is regained when the toad is placed on its back. At first the animal is able to turn over in a few seconds but as the asthenia progresses it remains longer and longer on its back, with the four legs flexed and contracted on the body or, more rarely, extended. (Fig. 1.) Grotesque, catatonic movements may be observed. After some minutes the animal succeeds with some difficulty in righting itself. The failure of this postural reflex is not due to paralysis, progression is effected by crawling instead of by the normal jumping. The eroaking reflex, however, persists. As the asthenia and adynamia progress, the lack of movement becomes so complete that only the heart beats give signs of life.

Convulsions may be observed during any stage of the asthenia. They resemble those of strychnine and, even more closely, those due to insulin. The hind legs kick together or separately, the fore legs cross each other, there are tonic 
spasms separated by clonic ones or by periods of paralysis. These convulsions are usually observed in 3 to 10 per cent of the preparations, but in one group they reached 50 per cent. Feeding (with ox or frogs' meat or frogs' liver or worms) aggravates the convulsions and causes them to become more frequent.

The asthenic symptoms may be prevented by implantation or injection of the principal lobe of the toad, or of the neuro-intermediate lobe. The latter is less active as are also both mammalian anterior and posterior lobes. ${ }^{52,53,56,60,114}$ If the asthenia and convulsions are not very severe these injections or implantations will cure them. They will also prevent or counteract the toxic effect of insulin. ${ }^{60}$ On the other hand the asthenia is not checked or cured by glucose, adrenin or cortin; indeed, the adrenals of asthenic toads fifty days after operation have the same amount of adrenin as have the controls. ${ }^{62,53,58}$

The asthenia is due to metabolic alterations which affect the central nervous functions first and later, to a lesser degree, the muscular. That this is so is proved by the following facts: (1) The first sign is an alteration of the postural reflex which occurs even while movement is forceful, sensitiveness is preserved and the gait is normal. (2) The convulsions occur together with the asthenia, their origin is central because they cease in either limb when the mo-

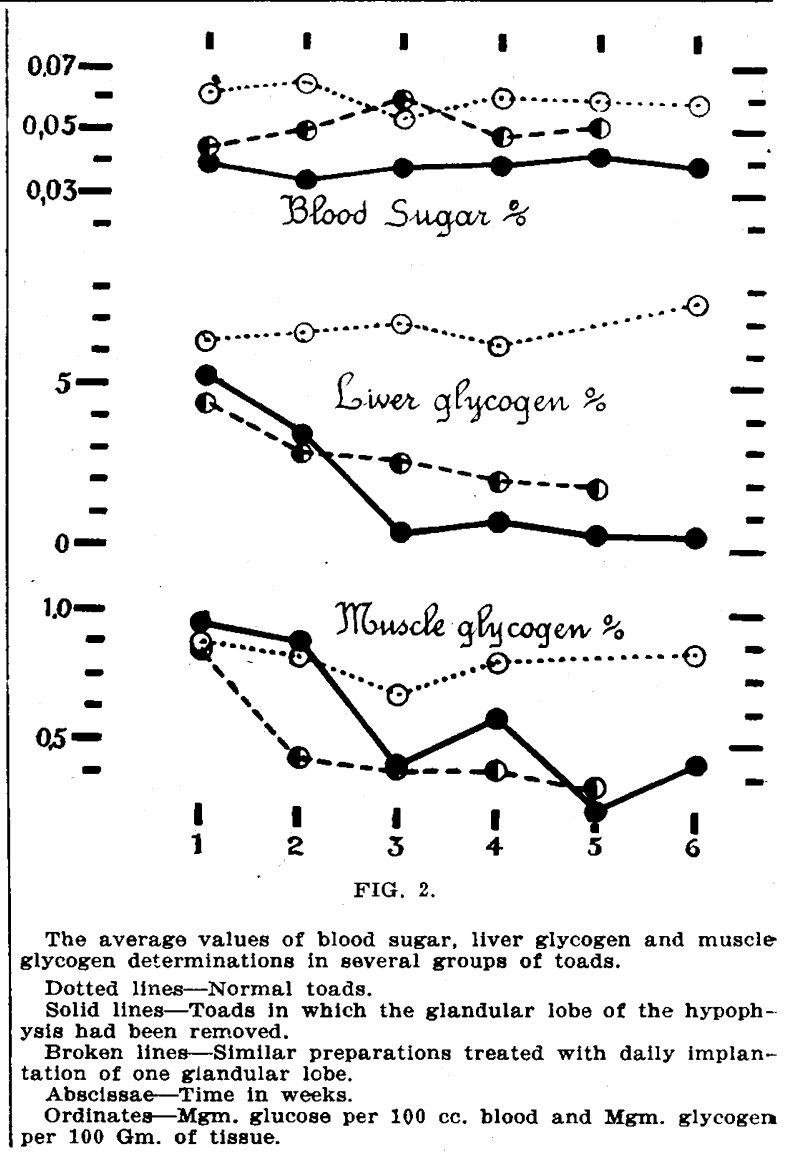

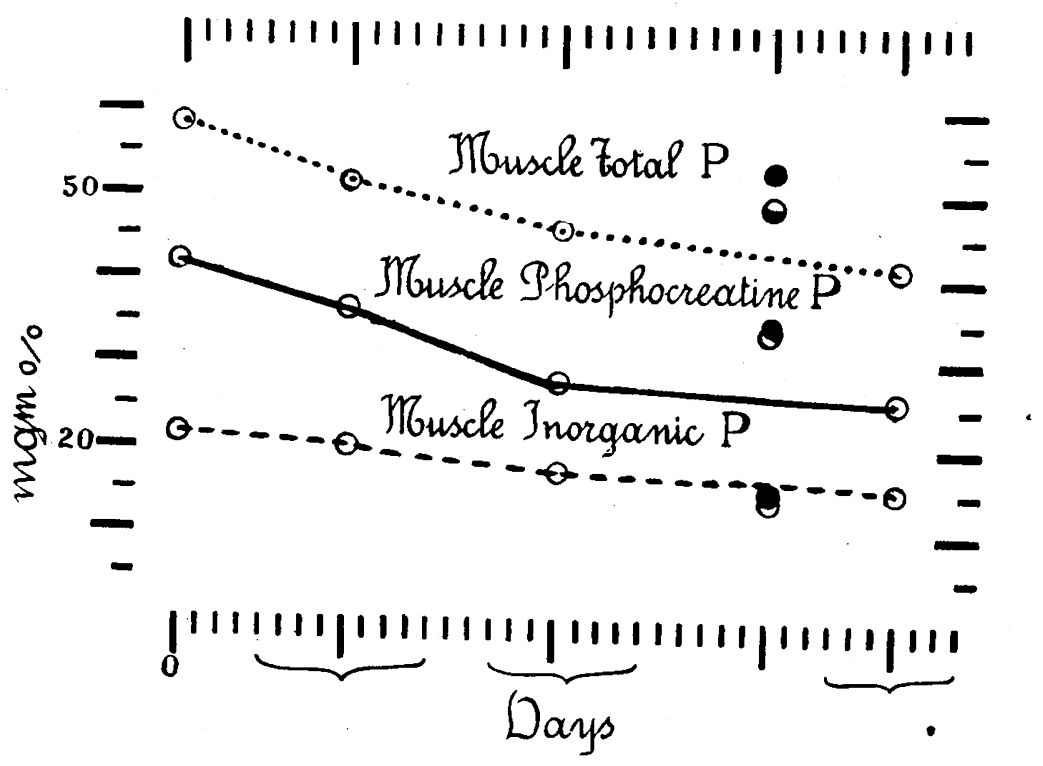

FIG. 3 .

The average values of determinations of the total phosphorus, phosphocreatine phosphorus and inorganic phosphorus in the gastrocnemius muscles of several groups of toads.

O Hypophysectomized toads.

- Hypophysectomized toads treated with daily implantations of the principal lobes of toads for three to nine days.

- Hypophysectomized toads treated with dally infections of alkaline extract of bovine anterior lobe $(0.5 \mathrm{cc}$. containing $0.1 \mathrm{Gm}$.) for eight to sixteen days.

Abscissae-Time in days.

Ordinates-Mgm. P per $100 \mathrm{Gm}$. muscle. 
tor nerves are cut. (3) There is a more rapid fatigue in the reflexes following acid (Houssay) or electrical stimulation, ${ }^{25}$ and the reflexes disappear altogether in severe asthenia. ${ }^{25}$ (4) Centripetal stimulation of the sciatic nerve causes, besides the rapid fatigue of the crossed reflex, rise and instability of the rheobase. (5) There is a quite exact correlation between the appearance of these changes and the asthenia. (6) The muscular and nervous chronaxie is normal except for an increase in both rheobase and chronaxie of the muscles when the asthenia becomes extreme. ${ }^{25}$ (7) When the asthenia is well developed the ergographic curve* of the gastroenemius, on stimulation of the sciatic, gives 74 to 80 per cent of work in the hypophysectomized and 86 to 95 per cent in those with le-

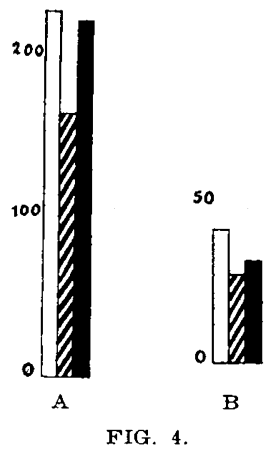

The average values of determinations of $A$, liver and $B$, muscle glutathione in several groups of toads recorded as $\mathrm{Mgm}$. per $100 \mathrm{Gm}$. tissue.

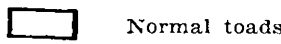

WWW Hypophysectomized toads.

$\therefore \quad$ Hypophysectomized toads injected with bovine glandular lobe extract.

sions of the tuber, as compared with that given by craniotomized animals. ${ }^{33,50,54,57}$

The general and muscular metabolic changes have been studied, but those of the central nervous system have not. The alterations occurring in hypophysectomized toads, or in those without the anterior lobe, can be prevented or corrected (partly or entirely) by mammalian anterior pituitary lobe or by the principal lobe of the toad; the posterior mammalian lobe and the neuro-intermediate toad lobe have a less effective action. $\dagger$ The metabolic changes which have been found are as follows: (1) The blood sugar is slightly lowered. ${ }^{65,59}$ (Fig. 2.) (2) The glycogen decreases earliest, and to the greatest extent, in the liver, ${ }^{55,59}$ later in the heart ${ }^{85}$ and finally, but to a lesser degree, in the muscles.56, 59 (Fig. 2.) (3) The phosphocreatine (and also the total phosphorus) of the muscles is lowered, particularly during the second

*Load $100 \mathrm{Gm}$., one maximal (faradic) stimulation per second for ten minutes.

$\dagger$ These are not only less active, but also more toxic. week; the inorganic phosphorus is much less affected. ${ }^{79} \quad$ (Fig. 3.) (4) The muscular and hepatic glutathione diminishes. ${ }^{79}$ (Fig. 4.) (5) The resting muscular lactic acid is normal, ${ }^{9}$ but it increases less during tetanus, than in the controls. ${ }^{80}$ (Fig. 5.)

150

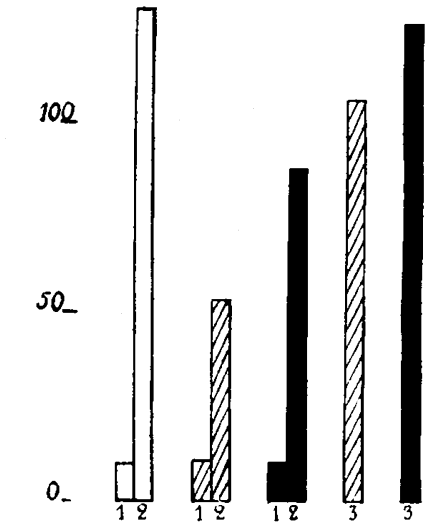

FrG. 5. The average values of determinations of lactic acid in the muscles of several groups of toads under different experimental conditions recorded as $\mathrm{Mgm}$. per $100 \mathrm{Gm}$. of muscle.

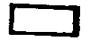

Normal toads.

$\mathrm{SN}$

Hypophysectomized toads.

Toads in which the glandular lobe only had been removed.

1. Resting muscle.

3. Contracting muscle. in hypophysectomized preparations which had received implantations of two or three toad glandular lobes.

Neuromotor and psychic changes in man

Pituitary cachexia or Simmonds' disease is seen in patients with serious destructive lesions of the pituitary.* The symptomatology has been reviewed by Graubner, ${ }^{43}$ Calder $^{18}$ and Silver ${ }^{103}$ who have gathered together and analyzed several dozen published cases. The principal symptoms noted and somewhat variously described by a number of authors include the following: a progressive wasting, which may lead to extreme emaciation; loss of the hair and changes in the skin; marked muscular weakness, asthenia and even intense adynamia; mental weakness, apathy or indifference or mental changes varying from stupidity to intense excitement, and sometimes alterations of personality; states of collapse, giddiness and fainting fits; an appearance of premature senility; loss of appetite, digestive upsets; sexual changes, particularly amenorrhea, frigidity and impotence; lowered B. M. R. and lessening of the specific dynamic action of foods ; lowering of body temperature and blood pressure; hypersensitivity to insulin;

*There is a smaller number with cerebral or tuberal lesions (see Pende's Review, 83 etc.) 
sometimes convulsions and sleepiness, and even coma and death.1, 4, 9, 13, 15, 17, 18, 19, 20, 23, 29, 35, $39,43,54,65,69,71,72,75,82,88,94,102,104,105,111,113$, $115,118,121$, etc.

In many cases of the polyglandular endocrine insufficiency of Claude and Gougerot the pituitary hypofunction no doubt plays the leading part.

In patients in whom the pituitary has been removed the following symptoms have been observed: indolence, extreme psychic changes, sleepiness, immobility, lowered temperature, etc. $^{15}$ Various cases suffering from pituitary insufficiency and even cases of myasthenia gravis $^{108}$ have been improved with whole or anterior pituitary lobe.1, 14, 17, 18, 23, 25, 26, 61, 65, 76, 92, 94, 112, etc. Falta $^{39}$ has noted apathy and mental symptoms in cases of dystrophia adiposogenitalis. In cases of pituitary infantilism there is a persistence of the infantile mentality.

Soon after the discovery of acromegaly, attention was drawn to the frequency with which it was accompanied by mental changes. ${ }^{10,16}$ Brunet found them in ten of the thirty-eight cases described in the thesis written by Souza Leite under the direction of Pierre Marie. Brunet differentiates those symptoms which are typical of the disease. (weakening of the intellect and memory, apathy, somnolence, obtuseness) and those due to mental degeneration from hereditary or other causes (misanthropy, hypochondria, melancholia, suicidal mania). Mark, ${ }^{81}$ an English doctor, made an interesting study of his own symptoms noting in particular the asthenia, feeling of tiredness, loss of energy, etc. Atkinson $^{5}$ has made a summary of all the literature on the subject.

Cushing $^{28}$ declared that a large number of the patients with pituitary disease show mental irregularities of one or another nature. From the etiologic point of view there are two types: (1) those in which there is involvement of the temporal or frontal lobes or other areas due to invasion by or pressure from the tumors; (2) those where there is increase, alteration or insufficiency of the secretion. Patients with pituitary overactivity suffer from inability to concentrate, indecision, and psychasthenic states. If the illness originates in childhood there is a low grade of intelligence. In cases of pituitary insufficiency there can be all stages of mental change from light psychoses to extreme mental alteration. Some patients with pituitary disease have epilepsy.

Many investigators attribute a leading rôle to the diencephalon since analogous symptoms occur in cases with lesions of the third ventricle or cerebral peduncles and, above all, in encephalitis lethargica. According to them there are lower and higher psychic centres; $;^{21,34,74}$ and centres for the affections, impulses, desires, and nutritive or vegetative functions. ${ }^{72}$ Cases of tumor of the third ventricle or tumors causing pressure on the diencephalon according to Camauer $^{19}$ are characterized by apathy, mental confusion, an indifferent or masklike face, loss. of memory, anorexia, sluggish sexual impulses, incoherence and confused states, flight of ideas, ete.

A certain number of cases of pituitary tumor collected by Salmon ${ }^{100}$ show sleepiness but the experimental ${ }^{46}$ and clinical data $a^{20,36,73}$ indicate that this is due to the concomitant diencephalic lesions. The phantastic theory put forward by Zondek and Bier (1932) concerning the existence of a pituitary hypnotic hormone has no serious chemical basis.

Certain diencephalic lesions can give rise to epileptic convulsions ${ }^{83}$ which have been observed in human beings, ${ }^{89}$ and lead some investigators to believe there is an epileptogenic centre. ${ }^{101}$

\section{Pituitary asthenia and the adrenals}

Pituitary insufficiency always causes atrophy of the adrenal cortex* (particularly of the internal layers) in the rat and less frequently in the dog. It has been observed in human hypopituitarism but has not been proved to exist in the toad.

Because of this, some investigators think pituitary cachexia is due to the accompanying adrenal insufficiency. Evans, Meyer, Pencharz, and Simpson ${ }^{37,38}$ observed that certain anterior pituitary extracts (but not the gonadotropic one) prevented or corrected the adrenal cortical atrophy and simultaneously the asthenia in hypophysectomized rats, with the result that the muscular force, tone and turgidity were surprisingly improved. These authors failed to obtain equivalent results by the use of cortin, although others have done so, e.g., Atwell ${ }^{6}$ found that the asthenia and lowered temperature were improved and there was a partial recovery of spontaneous activity, without, however, any alteration in the atrophy of the adrenals; Perla ${ }^{90}$ found that there was an increased resistance to the toxic action of histamine; Baird, Cloney and Albright ${ }^{8}$ found disappearance of the extreme sensitiveness to cold; and $\mathrm{Kalk}^{63}$ was able, by using cortin, to improve a case of human pituitary cachexia which had been resistant to anterior pituitary extracts. Cortin also seems to diminish the high postoperative mortality in hypophysectomized chickens ${ }^{47}$ but I have not found any benefit from its use in the asthenia of toads.

Injection of anterior pituitary extract does not prolong the life of adrenalectomized rats, ${ }^{3 \varepsilon}$ dogs or toads. (Houssay and Leloir, unpublished.)

Grollman and Firor $^{44}$ draw attention to the

* See our paper ${ }^{52}$ (with detailed bibliography) on the functional 
similarity between the symptoms of pituitary cachexia and chronic adrenal insufficiency. They were able to improve cases of the latter with anterior pituitary extract but not with adrenal cortical extract* thus giving rise to the supposition that the adrenal insufficiency causes some pituitary alteration leading to hypofunction which is manifested by stoppage of growth, reproductive incapacity and lowered temperature.

Certain cases of pituitary basophilism have shown asthenia, and extreme weakness. Cushing $^{30}$ suggests that these symptoms have an adrenal origin.

\section{GENERAL SUMMARY}

In the advanced stages of confirmed pituitary insufficiency there is a neuromuscular asthenic syndrome which occurs constantly, in: tensely and characteristically in the toad, during certain stages in the rat, and in a less marked form and not so constantly in the dog. It is very well developed in human cases of pituitary cachexia.

The syndrome seems to result mainly from functional changes in the central nervous system, the peripheral motor changes playing only a secondary rôle. Evidence for this is given by: (1) the experimental analysis carried out in the asthenic toad; (2) the early and marked alteration in the postural and phasic reflexes in these toads, while the motor nerve and muscular excitability is still normal; (3) the coexistence of convulsions of central nervous origin with the asthenia; (4) the association with mental alterations in human cachexia and the changes in behavior of other animals; (5) the lowered blood pressure and hypodynamic vascular reactions. (See our lecture on, Hypophysis and Blood Pressure. $t$ )

The functional changes seem to have a metabolic origin since they coincide with general nutritive changes (decrease of blood sugar and glycogen, increase of sensitivity to insulin, decrease of the endogenous nitrogenous catabolism, etc.).

Adrenal insufficiency which occurs frequently in cases of pituitary insufficiency, probably increases the asthenia but it is not certain, nor even likely, that the asthenia has an exclusively adrenal origin. Cortin does not correct asthenia hypophysopriva as does the anterior pituitary extract. It is more probable that there is a direct metabolic action of the pituitary hormone. On the other hand the actions of the adrenals and pituitary on the carbohydrate metabolism have a certain similarity (the glycogenetic action, etc.) and anterior pituitary extract has a diabetogenic activity in adrenaleetomized toads.

* Only thyrotropic extracts corrected hypothermia.

†To appear in this Journal May 28, 1936.
Pituitary asthenia, therefore, appears to be due to general nutritive changes which principally affect the function of the central nervous system.

\section{REFERENCES}

1. Abel. E., and Kissel, P.: Rev. franc. d'endocrinol. 12:287 (Aug.) 1934.

2. Aschner, B.: Arch. f. d. ges. Physiol. 146:1, 1912 .

3. Ascoli, G., and Legnani, T.: München. med. Wchnschr. $59: 518,1912$.

4. Assmann, H.: Klin. Wchnschr. 47:1705, 1934

5. Atkinson, F. R. B.: Acromegaly. London: J. Bale. 1932.

6. Atwell, W. J.: Proc. Soc. Exper. Biol. \& Med. 29:1259 (June) 1932; Endocrinol. 16:639, 1932; Anat. Rec. 55:5, 1933. 7. Bailey, P., and Bremer, F.: Arch. Int. Med. $28: 773$ (Dec.)
1921.

8. Baird, P. C.. Jr.; Cloney, E., and Albright, F.: Am. J. Physioi. 104:489 (May) 1933.

9. Balo, J.: Klin. Wchrschr. 19:902 (May) 1923.

10. Barros, R.: These Fac. Med. Paris. 1908 .

11. Bell, W. B.: Quart. J. Exper. Physiol. 11:78, 1917; the Pituitary. London: Bailliere. 1919:

12. Berblinger, w.: Hirsch. Handb. inn. Sekr. 1:910, 1932.

13. Berblinger, w.: Endokrinol. 14:369, 1934.

14. Bostroem, A.: Med. Klin. 28:690 (July) 1918.

15. Borowskaja, W.: Vechnik Endokrinol. 4:382, 1934.

16. Brunet, L.: Thèse Fac. Med. Paris. 1899 .

17. Calder, R. M.: J. A. M. A. 98:314 (Jan. 23) 1932

17. Calder, R. M.: J. A. M. A. $98: 314$ (Jan. 23) 1932.
18. Calder, R. M.: Johns Hopkins Hosp. Bull. 50:87, 1932.
19. Camauer, A. F.: Prensa Medica Argentina 249, 1931.

19. Camauer, A. F.: Prensa Médica Argentina 249, 1931. hiporisaria F.: Clinica de la region tub

21. Camus, J.: Paris med. (Oct.) 1911; (Oct.) 1922; 14:316 (Oct.) 1924 .

22. Caselli, A.: Studi anatomici e Sperimentali sulla Fisiopatologia della glandola pituitaria. Reggio (Emilia) Calderini ed. 1900

23. Cervera, L.; Folch, A., and Benaiges, B.: Rev. Franc. Endocr. 12:15, 1934

24. Chiasserini : Policlinico (sez. Chir.) 20:11, 1913.

25. Cicardo, V. H.: Rev. Soc. argent. de biol. 11, 1935.

26. Constantini, F.: Policlinico 38, 1931.

27. Crowe, S. J.; Cushing, H., and Homans, J.: Johns Hopkins Hosp. Bull. $21: 127$ (May) 1910

28. Cushing, H.: The Pituitary Body and its Disorders. Philadelphia: J. B. Lippincott Co. p. 270, 1912. Am. J. Insanity $69: 965,1913$.

29. Cushing, H.: Lancet $8: 119,175,1930$.

30. Cushing, H.: Pituitary Body, Hypothalamus and Pa:asympathetic Nervous System. Thomas. 1932

31. Dalla Vedova, R.: Bull. d. r. Accad. med. di Roma 29:150, 1903 ; 30:137, 1904 .

32. Dandy, W. E., and Reichert, F. L.: Bull. Johns Hopkins Hosp. $37: 1,1925$.

33. Deuticke, H. J.: Arch. f. d. ges. Physiol. $227: 24,1931$.

34. Dide, M.: Rev. neurol. $41: 941,1934$.

35. Di Guglielmo: Sindromi neuro-ipofisarie, 1929

36. Economo, C.: tber den Schlaf. Springer. 1925: Ergebn. Physiol. 28:312, 1929.

37. Evans, H. M.; Meyer, K.; Pencharz, R. I., and Simpson, M. E.: Science $75: 442$ (April) 1932

38. Evans, H. M.; Meyer, K.; Pencharz, R., and Simpson, M. E.: Memoirs Univ. California $11: 319,322,339,1933$.

39. Falta, W.: Die Erkrankungen der Blutdrüsen. pp. 255 , 390,$1913 ; 1928$.

40. Friedmann, F., and Maas, O.: Berl. klin. Wchnschr, 52 $1213,1900$.

41. Gatta: Gazz. d. Osped. e. d. Clin. 146, 1896.

42. Gemelii, A.: Arch. ital. de biol. 50:157, 1908 .

43. Graubner, W.: Ztschr. klin. Med. $101: 249$, 1925. 44. Grollman, A., and Firor, W. M.: Am. J. Physiol. 112:310
(June) 1935.

45. Hantschmann, L.: Deutsches Arch. f. klin. Med. $176: 397$,

1934.
46. Hess, W. R.: Compt. rend. Soc. de biol. 107:1333, 1931; Klin. Wchnschr. 12:129, 1933; Beitrage zur Physiologie des Hirnstammes. Chieme Leipzig 1932

47. Hill, R. T.; Corkill, A. B., and Parkes, A. S.: Proc. Roy. Soc. London B. 116:208, and Parkes,

48. Hill, M., and Parkes, A. S.: Proc. Roy. Soc. London. B. 112:138 (Dec. 1) 1932.

49. Horsley, V.: Lancet $5,1886$.

50. Houssay, B. A.: Rev. Univ. Bs. As. 13:89, 1910; Prensa Med. Argent. 8:8, 1916; J. Physiol. Pathol. Gener. 18:406, Med.

51. Houssay, B. A.: Actas 1er Congr. Nac. Medic. Bs. As. 4:40, 1916 .

52. Houssay, B. A.: Prensa Méd. Argent. 20:1563, 1933

52. Houssay, B. A.: Prensa Med. Argent. $20: 1563,1933$.
53. Houssay, B. A.: Rev. Soc. argent. de biol. 9:34, 1933 ; Compt. rend. Soc. de biol. 93:472, 1933.

54. Houssay, B. A.: Rev. Soc. argent. de biol. 11, 1935

55. Houssay, B. A.; di Benedetto. E., and Mazzocco, P.: Rev. Soc. argent. de biol. 9:4, 1933 ; Compt. rend. Soc. de biol. $93: 465,1933$.

56. Houssay, B. A., and Giusti, L.: Rev. Asoc. med. argent (Soc. de Biol.) $37: 155,1924$; Compt. rend. Soc. de biol.
91:313, 1924. 
57. Houssay, B. A., and Giusti, L.: Rev. Soc. argent. de biol. 6:47, 1929; Compt. rend. Soc. de biol. 101:935, 1929.

58. Houssay, B. A., and Mazzocco, P.: Rev. Soc. argent. de biol. 9:220 (July) 1933; Compt. rend. Soc. de biol. $114: 722,1933$.

59. Houssay, B. A.: Mazzocco, P., and Rietti, C. T.: Rev. Soc. argent. de biol. 1:227, 231, 1925 ; Compt. rend. Soc. de biol. 93:967, 968 (Oct. 23) 1925 .

60. Houssay. B. A., and Potick, D.: Rev. Soc. argent. de biol. 5:66, 1929; abstr., Compt. rend. Soc. de biol. 101:940 (July 17) 1929

61. Hürthle, R.: Med. Klin. 28:1637 (Nov. 18) 1932.

62. Kalk, H.: Deutsche med. Wchnschr. 60:893 (June 15) 1934.

63. Kalk, H.: See Ref. No. 62 .

64. Karlik, L. N., and Robinson, I. A.: Arch. f. d. ges. Physiol. $227: 480$, 1931; Arch. argent. de neurol. 12:61 (MarchApril) 1935

65. Kestner, O.; Liebeschutz-Plaut, R., and Schadow, H.: Klin. Wchnschr. 5:1646 (Sept. 3) 1926.

66. Koster, S., and Geesink, A.: Arch. neerl. de physiol. 13:601, 1928; Arch. f. d. ges. Physiol. 222:293, 1929.

67. Koyama, R.: Jap. J. M. Sc., Tr. IV, Pharmacol. 5:41 (March) 1931 .

68. Kriaschew, W. J.: Arch. f. d. ges. Physiol. 232:389, 1933.

69. Lang, F. J.: Wien. klin. Wchnschr. 37:977 (Sept. 25) 1924 .

70. Lascano-González, J. M.: Rev. Soc. argent. de biol.11:309 (Aug.) 1935.

71. Leschke, E.: Erkrankungen des vegetativen Nervensystems, Leipzig, 1931.

72. Leschke, E.: See Ref. No. 71, p. 38.

73. Lhermitte, J.: Le Sommeil, Paris, A. Colin, 1931.

74. Lhermitte, J.: Rev. neurol. 1:920 (June) 1934.

75. Lichtwitz, L.: Klin. Wchnschr. 1:1877 (Sept. 16) 1922.

76. MeGovern, B. E.: Endocrinol. 16:402, 1932 .

77. McPhail, M. K.: Proc. Roy. Soc. London. B, $117: 45$.

78. Mahoney, W.: Am. J. Physiol. 109:475 (Sept.) 1934.

79. Marenzi, A. D.: Rev. Soc. argent. de biol. 9:43 (May) 1933 ; Compt. rend. Soc. de biol. 114:394, 1933 .

80. Marenzi, A. D.: Rev. Soc. argent. de biol. 10:29, 1934.

81. Mark, L. P.: Acromegaly, a Fersonal Experience, London, Bailliere, Tindall and Cox, 1912.

82. Messedaglia, L.: Studi sull 'acromegalia, Padova, 1908.

83. Morgan, L. O.: Arch. Neurol. \& Psychiat. 24:267 (Aug.) 1930

84. Morgan, L. O., and Johnson, C. A.: Arch. Neurol. \& Psychiat. 24:696 (Oct.) 1930 .

85. Orias, O.: Rev. Soc. argent. de biol. 10:149 (June) 1934; Compt. rend. Soc. de biol. 117:59, 1934

86. Pappenheim: Wien. klin. Wchnschr. 47:148 (Feb. 2) 1934.

\section{A WISCONSIN GIRL WINS GORGAS ESSAY CONTEST}

Washington, D. C., May 7. Miss Helen Mae Collentine, a senior student at Messmer High School, Milwaukee, Wisconsin, today was awarded the First Henry L. Doherty Prize of $\$ 500$ in the Seventh Annual Gorgas Essay Contest. The subject assigned was "Gorgas' Control of Transmissible and Other Preventable Diseases." Thousands of junior and senior students representing high schools in all parts of the United States participated in the project which is conducted by the Gorgas Memorial Institute as a part of its health education program. A bronze Gorgas medal was awarded for the best essay written in each high school and a cash prize of $\$ 10$ was given for the best essay in each State. In addition to $\$ 500$, Miss Collentine received $\$ 200$ to defray the expenses of her trip to Washington.

PRESIDENT roosevelt PRESENTS PRIZE

President Roosevelt, in his capacity as Honorary President of the Gorgas Memorial Institute, presented the prize to Miss Collentine at the White House before a small group of distinguished guests, including Mrs. Henry L. Doherty, Mrs. Aileen Wrightson, daughter of General Gorgas; Dr. Bowman C. Crowell, of Chicago, and Admiral Cary T. Grayson, who is
87. Paulesco, N. C.: Morphologie de L'Hypophyse du Cerveau, Paris, Vigot, 1908

88. Pende, N.: Monitore di endocrinol. 2:453, 1934; Wien. med. Wchnschr. 84:594 (May 26) 1934; Endocrinologia, Milano, 1934 .

89. Penfield, W.: Arch. Neurol. \& Psychiat. $22: 358$ (Aug.) 1929 ; Canad. M. A. J. $30: 589$ (June) 1934 .

90. Perla, D.: Proc. Soc. Exper. Biol. \& Med. 32:797 (Feb.) 1935.

91. Pirrone, D.: Riforma med. 1:169, 1903.

92. Plaut, R.: Deutsches Arch. f. klin. Med. 139:285 (May) 1922 ; Deutsche Ztschr. f. Nervenh. 68:163, 1921.

93. Reichert, F. L.: Endocrinol. 12:451 (July-Aug.) 1928.

94. Reye: München. med. Wchnschr. 73:902 (May 28) 1926.

95. Richter, C. P.: Am. J. Physiol. 106:80 (Oct.) 1933.

96. Richter, C. P., and Wislocki, G. B.: Am. J. Physiol. 95:481 (Nov.) 1930.

ato, G.: Arch, 1. exper. Path. u. Pharmakol. 131:45, 1928

98. Saito, G.: Folia Endocr. Japon. 10:13 (April) 1934.

99. Sakamoto, A., and Saito, G.: Ztschr. ges. Exper. Med. $80: 601,1932$.

100. Salmon, A.: Il Cervello 6, 1923; 72, 1930; La fisiopatologia del Sonno. Bologna, L. Cappelli. 1930.

101. Salmon, A.: Presse méd. 40:20, 1932; 21:405, 1935.

102. Salus, F.: Med. Klin. 30:1160 (Aug. 3) 1934.'

103. Silver, S.: Arch. Int. Med. 51:175 (Feb.) 1933. 104. Simmonds, M.: Deutsche med. Wchnschr. 40:322 (Feb.) Imonds, J. P., and Brandes, W. W.: J. A. M. A. $84: 1408$ (May 9) 1925 .

106. Simon, H. E.: J. A. M. A. 104:2065 (June 8) 1935.

107. Smith, P. E.: J. A. M. A. 88:158 (Jan.) 1927 .

108. Smith, P. E.: Am. J. Anat. 45:205, 1930.

109. Solari, L. A.: V Congreso Nac. Medicina $3: 303,1934$.

110. Souza-Leite, J. D.: These Fac. Med. Paris. 1890.

111. Stocks, J. W.: Lancet $2: 349$ (Aug. 16) 1930.

112. Striker, C.: J. A. M. A. 101:1994 (Dec. 16) 1933.

113. Thannhauser, S. J.: Lehrbuch der Stoff wechsels und der Stoffaus, S. J.: Lehrbuch der stoffwech.

114. Ungar, I.: Rev. Soc. argent. de biol. 8:616, 1932; Compt. rend Soc de biol. 112:504, 1933.

15. 'Urechia, C., and Elekes, N.: Encéphale 21:352 (May) 1926. 16. Vassale, G., and Sacchi, E.: Riv. sper. di freniat. -255 , 1892 ; Arch. ital. de biol. 18:385, 1892-3.

17. Veccia, P.: Patologia dell'ipofisi. Napoli. 1913.

118. Wahlberg: Acta Med. Scandinavica 84:550, 1934; Finska Lakaresallskapets Handlingar 76:1059, 1934.

119. White, W. E.: Proc. Roy. Soc. London. B. 114:64 (Nov. 1) 1933 .

120. Zondek, H.: Klin. Wchnsthr. 27:1385, 1922; Die Krankheiten der endocrinen Drüsen. Berlin. 1926.

Chairman of the Board of the Gorgas Institute. Later in the day, Miss Collentine was presented in a nation-wide radio broadcast in which the winners of the other National Awards were announced.

OTHER PRIZE WINNERS

The Second National Prize of $\$ 150$ was given to Miss Peggy Weber of the Allen High School of New Orleans. Miss Grace C. Wiesner of Nazareth Academy, Rochester, New York, won the Third Prize of $\$ 50$. First Honorable Mention went to Mr. David G. Parkes, of Lincoln High School, Ferndale, Michigan, while the Second Honorable Mention was awarded to Miss Antoinette Kelly, College High School, Moorhead, Minnesota.

\section{ANOTHER CONTEST TO BE LAUNCHED}

Following the prize presentation of May 7, Admiral Grayson announced that the Eighth Annual Gorgas Essay Contest is to be launched in high schools next October. The subject will be "The Importance of Mosquito Control and the Gorgas Memorial." Dętails concerning the plan will be mailed to all high schools when the Fall term opens. In the meanlime, teachers and students are invited to write the Gorgas Memorial Institute, at Washington, D. C., for full information. 